\title{
Livy, the Reader Involved, and the Audience of Roman Historiography
}

\section{Introduction: From amateur historian to amateur readers*}

Modern approaches to ancient literature tend to disregard the author as a person outside his text as much as possible. Given the fact that we do not know very much about most of our writers, this is a rather easy task for the larger part of classical literature. Nevertheless, in the case of historiography, the extra-textual status of the author remains relevant not only for the simple knowledge of events, but also for certain matters of their presentation, as is especially evident in the case of autopsy. ${ }^{1}$ The same overlap between inter-textual and extra-textual experiences, however, exists on the part of the reader. It is, therefore, to be expected that individual readers react differently to the narration of a given event in an historical text according to their own past and to their actual life. To adduce no more than one example: Even the most rhetorical description of the sack of a city, as depicted in the handbooks for prospective orators like in Quintilian's Institutio, ${ }^{2}$ must have affected someone who had actually witnessed the capture of a city very differently from someone who had never seen any such thing. This holds true even if the witness had been on the victorious side: that not only the victim, but also the aggressor is affected by the events of war has been rightly highlighted as part of the attempts to use the concept of posttraumatic stress disorder for a better understanding of ancient societies. ${ }^{3}$

For this reason, in order to fully understand how ancient historiography works, we would need to know who the people actually were that took these scrolls into their hands and subsequently unrolled them, and why they continued to do so and what they thought and felt about it. This is, of course, far beyond our reach. ${ }^{4}$ What can be done in terms of an empirical analysis of the reception of ancient his-

\footnotetext{
* It has been an honour to be asked to deliver one of the two key note speeches, but it has been an even greater pleasure to return to Rauischholzhausen and to be part of such an inspiring conference. Furthermore, I would like to thank Dr Glenn Patten for reading the paper and polishing my English in various ways.

1 This holds true, of course, for modern historiography in a similar way. A specific narratology for factual texts, however, still has to be developed. For useful approaches already existing see, above all, Genette 1990 and Cohn 1999, especially 109-131; for further references see Pausch 2011, 9-12. 2 Cf. Quint. Inst. 8.3.67-69; see further Paul 1982.

3 See especially Meineck / Konstan 2014.

4 For attempts to define the ancient audience of classical historiography in general terms, see e.g. Momigliano 1978; Verdin / Schepens / de Keyser 1990, and Marincola 2009.
} 
toriography in antiquity, has been done recently by Marietta Horster. ${ }^{5}$ Her thorough analysis of the relevant papyri, inscriptions and citations in the work of authors from other genres suggests, however, that we have no sufficient reason to suppose that history was read in antiquity on a larger scale at all.

While these quantitative arguments are hard to refuse, in what follows I intend to take a more qualitative approach. In doing so, I will try to put together some of the external evidence that we have and to combine it with the imagined reader emerging from the works of the historians. To be sure, this has to be done for every single writer separately, and within the limits of this paper I will focus on Livy. Nevertheless, I hope that the results presented might be of some use for the discussion of other authors as well. In contrast to the book Livius und der Leser. Narrative Strukturen in Ab urbe condita, ${ }^{6}$ it is not my aim here to study the narrative techniques with the help of the reader, but to learn more about this very reader with the help of the narrative techniques employed by Livy.

While doing so, I will take for granted that readers of historiography both in our times and in antiquity are interested in historical knowledge for its own sake and above all - for its practical and moral value, as Lisa Hau has recently shown convincingly. ${ }^{7}$ I will place special emphasis, however, on the circumstance that there are beside these motives related to utility - clear signs that it was also perfectly acceptable, at least in Late Republican Rome, to read the work of a historian because it provided for entertainment - or for delectatio, if you prefer the wording used by Horace in his famous juxtaposition of aut delectare aut prodesse. ${ }^{8}$

Livy, of course, has been severely criticised precisely for his willingness to acknowledge pleasure as a part of the historian's task. But instead of blaming him for being an amateur historian once more, I would like to shed some light on his amateur readers, so to speak. For this purpose, we will take a close look at how Livy narrates his version of the past, assuming that this can tell us something about his ideas who his readers might have been and what motives he thought they had for reading his work on Roman history (and not the work of one his many rivals). Prior to this, however, I will try to give a short survey of the state of the discussion about how to write history in the time Livy decided to take up his pen and to spend his life writing $A b$ urbe condita.

5 See Horster 2018; for the papyrological remains especially from Livy see Funari 2011.

6 Cf. Pausch 2011.

7 See Hau 2016.

8 Cf. Hor. Ep. 2.3.333-334. 


\section{Reflecting about reading history in the Late Republic}

Although it remains true, of course, that our knowledge about the audience for historiography in antiquity is fairly limited compared to modern standards, we can get a few glimpses of what the contemporaries regarded as possible reasons for reading a work of history. ${ }^{9}$ Again, I will not dwell on the practical usefulness of the knowledge of the past, ${ }^{10}$ but will instead focus on the other part of the spectrum.

It is, as so often, Cicero who must raise his voice for the vast majority of his fellow Romans whose words and thoughts have been silenced by the fortuities of transmission. And indeed, he praises history for her benefiting effects on human life in general, as, for example, in his famous eulogy in De oratore. ${ }^{11}$ More intriguing is that the same Cicero, when it comes to historiography as a literary genre, shifts his focus from utilitas to delectatio. This holds true for his much-debated prescriptions for how history should be written, namely in the right style and ideally, of course, by an orator pretty much like himself. ${ }^{12}$ The same modification, however, can also be observed in his remarks on how history should be read. Above all, two passages out of his many works have proved to be of great value to anyone trying to reconstruct the Late Republican 'state of the art', so to speak. More prominent is his letter to the historian Lucceius, but we will start with a section of his dialogue $D e$ finibus for now.

During the summer months of 45 BCE, Cicero wrote - among other things - five books De finibus bonorum et malorum. ${ }^{13}$ In contrast to his usual practice, he chose three different settings for his conversations about what one could call a theory of ethics. This means that the passage relevant to us here, since it forms a part of the fifth book, stems from a discussion that Cicero claims to have had during his first visit to Athens back in 79 BCE with several of his fellow students. One of them, M. Pupius Piso Calpurnianus, is given the opportunity to expound his peripatetic views on human nature in a detailed argumentation. Among the points that Cicero especially wants him to bring home is the assumption that the quest for knowledge is deeply rooted in our soul and thus not motivated by utilitarian reasons alone. Admittedly, the focus of interest here clearly lies on philosophical knowledge, but inter-

9 For a similar analysis of later texts, see the contributions by Pauline Duchêne and George Baroud to the present volume.

10 As highlighted, for example, by Sallust; on his remarks about the purposes of history and his intended readers, see the contribution by Edwin Shaw in the present volume.

11 Cf. Cic. de Orat. 2, esp. 36: historia vero testis temporum, lux veritatis, vita memoriae, magistra vitae, nuntia vetustatis, qua voce alia, nisi oratoris, immortalitati commendatur?

12 Cf. Cic. de Orat. 2.51-64 and Leg. 1.6-7; see further e.g. Feldherr 2003, 196-212, and Fox 2007, $134-144$.

13 For the part historiography plays in Cicero's philosophy in general, see Fox 2007. 
estingly enough, Cicero seems to think that he can use - among others - the example of historiography as an obvious argument in order to prove the more controversial case for philosophy. This is what happens in our passage (Cic. Fin. 5.51-52): ${ }^{14}$

sed quid attinet de rebus tam apertis plura requirere? ipsi enim quaeramus a nobis stellarum
motus contemplationesque rerum caelestium eorumque omnium, quae naturae obscuritate occul-
tantur, cognitiones quem ad modum nos moveant, et quid historia delectet, quam solemus per-
sequi usque ad extremum, <cum> praetermissa repetimus, inchoata persequimur. nec vero sum
nescius esse utilitatem in historia, non modo voluptatem. quid, cum fictas fabulas, e quibus utilitas
nulla elici potest, cum voluptate legimus? quid, cum volumus nomina eorum, qui quid gesserint,
nota nobis esse, parentes, patriam, multa praeterea minime necessaria? quid, quod homines in-
fima fortuna, nulla spe rerum gerendarum, opifices deinque delectantur historia? maximeque
eos videre possumus res gestas audire et legere velle, qui a spe gerendi absunt confecti senec-
tute. quocirca intellegi necesse est in ipsis rebus, quae discuntur et cognoscuntur, invitamenta
inesse, quibus ad discendum cognoscendumque moveamur.

But what is the point of inquiring further into matters so obvious? Let us ask ourselves the question, how it is we are interested in the motions of the stars and in contemplating the heavenly bodies and studying all the obscure and secret realms of nature; why we derive pleasure from history, which we are so fond of following up, to the remotest detail, turning back to parts we have omitted, and pushing on to the end when we have once begun. Not that I am unaware that history is useful as well as entertaining. But what of our reading fiction, from which no utility can be extracted? What of our eagerness to learn the names of people who have done something notable, their parentage, birthplace, and many quite unimportant details beside? What of the delight that is taken in history by men of the humblest station, who have no expectation of participating in public life, even mere artisans? Also we may notice that the persons most eager to hear and read of public affairs are those who are debarred by the infirmities of age from any prospect of taking part in them. Hence we are forced to infer that the objects of study and knowledge contain in themselves the allurements that entice us to study and to learning.

The second part of this passage is cited more often, ${ }^{15}$ since it contains some of the few hints we can use if we want to come to a more refined description of the readership of historiography in social terms. ${ }^{16}$ On the one hand, it fits nicely into the argument of Tim Wiseman's sweeping book on The Roman Audience, since it highlights the fact that hearing is an equivalent form of reception of history in antiquity. ${ }^{17}$ On the other hand, the words put into the mouth of Piso here can be taken as an important proof for the final phase of a longer lasting development, namely the enlargement of the readership for historical works during the Republic, not only due to the expansion of the Roman Empire and the subsequent growth of the number of Latin-speaking contemporaries, but also due to a widening of potential readers with regard to different groups within the same society. ${ }^{18}$ The usual and rather dis-

14 Text by Schiche 1961; translation by Rackham 1961.

15 Cf. e.g. Malitz 1990, 339-340; Walter 2004, 212-213, and Marincola 2009, 13.

16 For further discussion, see now de Franchis 2014, 192-194.

17 See Wiseman 2015, especially 98-102 (Caesar); 115-118 (Sallust); 129-131 (Livy).

18 Cf. e.g. Pausch 2011, 65-70, and de Franchis 2014, 194-199. 
missive reaction to this observation is the one reflected here by Cicero's Piso, too: why do people who will never be able to make history read history at all? Since utilitas is beyond their reach, for them it must be all about delectatio. Hence, they are (part of) the reason for the decline of historiography as it should be - at least in an ideal upper-class world of properly educated soon-to-be statesmen.

Since Cicero is aiming at something completely different here, he only uses the elements of this traditional picture, and gives them another direction. This already becomes apparent when Piso mentions the similar problem resulting from readers of history who are so aged that their active life already lies behind them. But it is above all the first part of the passage that is at odds with such expectations: before even starting to differentiate possible readers into groups, Cicero lets his Piso argue for the pleasure (using the word voluptas, an even more striking expression than delectatio) resulting from reading history as no less important than utilitas for him personally and for everyone that he can imagine as his reader, and this surely comprises all of his peers, future generals and statesmen alike.

The impression that Cicero knows about a classification into professional and amateur readers of historiography, but readily incorporates both himself and his own readers under the second heading gets even stronger when we now turn to his famous letter to the historian L. Lucceius, who had been praetor urbanus in 67 BCE. ${ }^{19}$ Written in 56/55 BCE, this rather long letter follows one clear goal: Cicero wants Lucceius to write an historical monograph about his consulship, with due regard to his suppression of the Catilinarian conspiracy. ${ }^{20}$ Lucceius apparently refused (or the work is lost without leaving any traces), but Cicero cannot be blamed for not giving his very best to try to convince him. Again, the argumentative context is of great importance for a proper understanding of Cicero's remarks about reading history (Cic. Fam. 5.12.4-5): $:^{21}$

multam etiam casus nostri varietatem tibi in scribendo suppeditabunt plenam cuiusdam voluptatis, quae vehementer animos hominum in legendo te scriptore tenere possit. nihil est enim aptius ad delectationem lectoris quam temporum varietates fortunaeque vicissitudines. quae etsi nobis optabiles in experiendo non fuerunt, in legendo tamen erunt iucundae. habet enim praeteriti doloris secura recordatio delectationem; ceteris vero nulla perfunctis propria molestia, casus autem alienos sine ullo dolore intuentibus, etiam ipsa misericordia est iucunda. quem enim nostrum ille moriens apud Mantineam Epaminondas non cum quadam miseratione delectat? qui tum denique sibi evelli iubet spiculum postea quam ei percontanti dictum est clipeum esse salvum, ut etiam in vulneris dolore aequo animo cum laude moreretur. cuius studium in legendo non erectum Themistocli fuga redituque retinetur? etenim ordo ipse annalium mediocriter nos retinet quasi enumeratione fastorum; at viri saepe excellentis ancipites variique casus habent admirationem, exspectationem, laetitiam, molestiam, spem, timorem; si vero exitu notabili concluduntur, expletur animus iucundissima lectionis voluptate.

19 It is only in this letter, however, that we hear about his profession as historian; see e.g. Fleck 1993, 199-202.

20 See further, e.g., Hall 1998 and Fox 2007, 256-263.

21 Text by Shackleton Bailey 1988; translation by Shuckburgh 1908-1909. 
For my vicissitudes will supply you in your composition with much variety, which has in itself a kind of charm, capable of taking a strong hold on the imagination of readers, when you are the writer. For nothing is better fitted to interest a reader than variety of circumstance and vicissitudes of fortune, which, though the reverse of welcome to us in actual experience, will make very pleasant reading: for the untroubled recollection of a past sorrow has a charm of its own. To the rest of the world, indeed, who have had no trouble themselves, and who look upon the misfortunes of others without any suffering of their own, the feeling of pity is itself a source of pleasure. For what man of us is not delighted, though feeling a certain compassion too, with the death-scene of Epaminondas at Mantinea? He, you know, did not allow the dart to be drawn from his body until he had been told, in answer to his question, that his shield was safe, so that in spite of the agony of his wound he died calmly and with glory. Whose interest is not roused and sustained by the banishment and return of Themistocles? Truly the mere chronological record of the annals has very little charm for us - little more than the entries in the fasti: but the doubtful and varied fortunes of a man, frequently of eminent character, involve feelings of wonder, suspense, joy, sorrow, hope, fear: if these fortunes are crowned with a glorious death, the imagination is satisfied with the most fascinating delight which reading can give.

In the reminder of the letter, Cicero discusses at length the problem of how the commemoration of his own person might be achieved without bending the leges historicae too much. What is entirely missing, however, in this array of arguments that he deemed suitable to convince Lucceius to write about him, is anything related to the utilitas of the events he would so much have liked to be described by the historian. This is even more astonishing, since it would have not been too difficult to illustrate the usefulness for further magistrates of the knowledge how the res publica had been saved from a serious threat in the shape of the conspiracy of the Catilinarians. But instead, he strongly focuses on the delectatio and voluptas that the reading of historiography causes in the mind of its readers as the key argument to win over Lucceius' favour.

Of course, both Lucceius as a writer and Cicero as a reader might have been exceptions with particularly bad taste. ${ }^{22}$ But if we rule out the praetor of 67 BCE and the consul of $63 \mathrm{BCE}$ as not serious enough, it will prove rather difficult to find many professional readers of historiography in Rome at all. To be sure, Lucullus seems to have read res gestae on his way to his command in Asia Minor, in order in prepare himself for the task against Mithridates (at least according to Cicero), ${ }^{23}$ and Sallust's Marius criticizes his noble predecessors for trying to learn their politics from books. ${ }^{24}$ Cicero's insistence on the entertainment resulting from historiography, however, seems to have been part of the usual expectations readers had towards this genre.

22 For assuming a fondness of 'tragic historiography' on the part of Cicero, see e.g. Reitzenstein 1906, 84-91, and Foucher 2000, 782-785; for a good survey, see Nicolai 1992, 164-176.

23 Cf. Cic. Ac. 2.1.2: itaque cum totum iter et navigationem consumpsisset partim in percontando a peritis partim in rebus gestis legendis, in Asiam factus imperator venit, cum esset Roma profectus rei militaris rudis. Cicero also mentions that Scipio read the Cyropaedia: cf. Cic. Q. fr. 1.1.23; see further Hose 1994, 36-37.

24 Cf. Sal. Jug. 85.12-13; see further Marincola 2009, 12-13. 
In this context, it is no minor point that Cicero's relevant remarks are written before the civil war and the end of the republic. This may look like splitting hairs, but it contradicts the traditional view that the focus on delectatio instead of utilitas is the result of the lost opportunity to participate in politics and thus prevailed at Rome not before the beginning of the empire. Cicero, however, already highlights the entertaining aspects of history in the years of his ongoing political career.

Before moving on towards Livy, we will take one quick step back to Polybius. It is, of course, an obvious idea to compare the developments at Republican Rome to those that took place some hundred years ago in the Hellenistic World. In both cases, the 'social downgrading' of writers and readers of historiography alike has been used as a handy explanation for the incorporation of more literary elements into the works of history. ${ }^{25}$ This view has been widely accepted, not least because it was put forward by the contemporaries themselves. Polybius, for example, in a much-cited passage from the proem of the ninth book of his Histories distinguishes between three different kinds of typical readers of historiography (Plb. 9.1.2-5): ${ }^{26}$

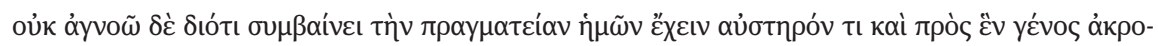

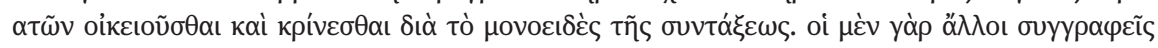

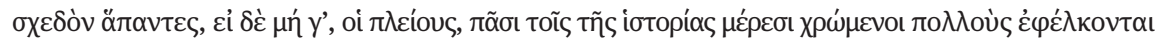

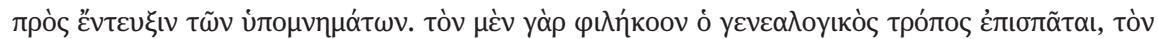

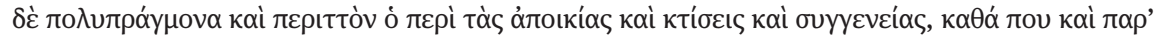

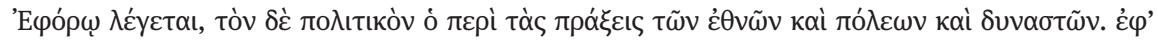

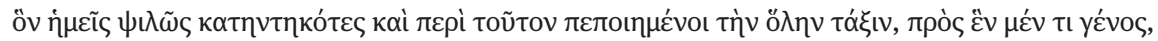

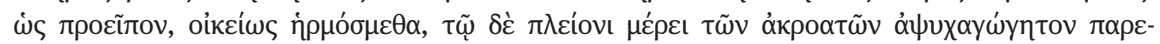

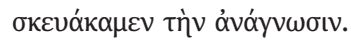

I am not unaware that my work owing to the uniformity of its composition has a certain severity, and will suit the taste and gain the approval of only one class of reader. For nearly all other writers, or at least most of them, by dealing with every branch of history, attract many kinds of people to the perusal of their works. The genealogical side appeals to those who are fond of a story, and the account of colonies, the foundation of cities, and their ties of kindred, such as we find, for instance, in Ephorus, attracts the curious and lovers of recondite lore, while the student of politics is interested in the doings of nations, cities, and monarchs. As I have confined my attention strictly to these last matters and as my whole work treats of nothing else, it is, as I say, adapted only to one sort of reader, and its perusal will have no attractions for the larger number.

Although the influence not only of Polybius' practice, but also of his methodological remarks on the development of Latin historiography from the middle of the $2^{\text {nd }}$ century BCE onwards, ${ }^{27}$ can hardly be underestimated, this passage turns out to be a disappointment. ${ }^{28}$ It is not too hard to guess that it is mainly intended to show another

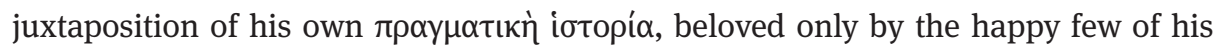

25 Cf. e.g. Malitz 1990, 323-327; for a more nuanced view, see Hose 2009, especially 191-192.

26 Text by Büttner-Wobst 1995; translation by Paton 1993.

27 On Polybius' 'paradoxical impact' on Latin historians, see Pausch 2018 (with further references).

28 For a more positive assessment, see e.g. Nicolai 2007, 23-24, and Näf 2010, 185-187. 


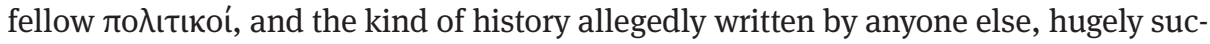
cessful with the ignorant crowd. Admittedly, this second group is further differentiated into those who love to hear good stories, the $\varphi$ ı $\lambda$ ńко , and those who are interested in remote historical details, the $\pi \varepsilon \rho \iota \tau$ of $^{\prime}$ albeit these details will usually be presented in the form of a good story. On closer inspection, though, the whole division fails to convince. If we take Cicero as a test case and are willing to accept the motives he named in the passages above, he would fit perfectly into every single one of the three categories presented by Polybius.

Given the lack of further testimonies, it is, of course, hard to decide if Cicero is a typical reader of historiography in the Late Roman Republic or if he rather is an exceptional figure, too interested in literature and too prone to yield to his emotions while hearing a good story. ${ }^{29}$ What we can do, however, is have a look at the way Livy writes his version of Rome's history during the following years and, in doing so, address the question of what kind of reader he might have had in his mind as the ideal counterpart in this conversation. In doing so, my idea is not to prove that a Cicero revived would have been the perfect incarnation of Livy's imagined reader, not least because the same question put the other way around, namely whether Cicero would have appreciated Livy's work, has been asked and answered in various ways already. ${ }^{30}$ For all the importance Cicero surely had, I will use him here only as one known reader of history in the Late Republican Rome and not as a fascinating person in his own right.

\section{Writing to engage the reader: Livy on Hannibal}

When we now turn to Livy's Ab urbe condita, one would expect that the praefatio might be the place the author uses to define both his own role in the following conversation and the type of reader he has in mind as his ideal counterpart. ${ }^{31}$ If we take him at his word here, however, he indeed desires to be nothing more than another

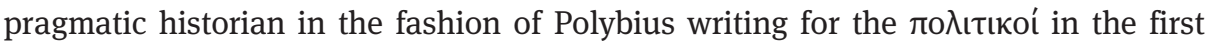
place. $^{32}$ To be sure, he mentions the voluptas of his readers and his own pleasure in dealing with the remote past in passing, ${ }^{33}$ but the bulk of the praefatio is about

29 Cf. Vitr. pr. 5.1: historiae per se tenent lectores; habent enim novarum rerum varias expectationes.

30 Cf. e.g. Leeman 1955; Moles 1993, 146-147; Feldherr 2003, 204, and Mineo 2006, 20.

31 For an analysis of the praefatio asking for whom Livy claims to write, see now in general de Franchis 2014.

32 There are some hints, however, that his intended audience might be more comprehensive; see de Franchis 2014, 207: "Il propose donc paradoxalement à ses lecteurs une histoire pragmatique, dans la lignée de celle de Polybe, mais avec la différence fondamentale que les leçons qu'on peut en tirer sont accessibles à tous (omnis te exempli documenta in inlustri posita monumento intueri), et non destinées à une minorité."

33 Cf. Liv. pr. 4-5: et legentium plerisque haud dubito, quin primae origines proximaque originibus minus praebitura voluptatis sint, festinantibus ad haec nova, quibus iam pridem praevalentis populi 
the usefulness of historical exempla as well as the greatness of both the city of Rome and her inhabitants. ${ }^{34}$ In other words, it pays a kind of 'lip service' to the principles of serious historiography on the one hand and to the usual local patriotism of classical writers on the other hand, and does both in a way that might be expected from the kind of newcomer on the field that Livy was at this stage of his career.

To be sure, the expectations raised by this 'advertising text' are truly fulfilled in the work that follows. There are, however, numerous passages even in the surviving parts of $A b$ urbe condita that do not lend themselves to classification in this vein and, thus, give rise to serious doubts about whether the thoughts expressed in the praefatio really were at the heart of his project as a whole. Furthermore, it is not even clear for which part of the ultimately 142 books Livy wrote this praefatio was originally intended. There is some reason to believe that it was designed to open up the first pentad alone. ${ }^{35}$ But even if it was meant for the entire project the young historian started around 27 BCE, it seems only natural that some changes might have occurred in the more than forty years to come. The most obvious explanation for the differences between praefatio and work proper, however, is that statements made by an historian - like by any other writer - about his own text are not always as reliable as we would wish. ${ }^{36}$

This is the reason why we will now leave the methodological remarks made by Livy in his praefatio as well as in a few other passages behind and move on to the way he narrates history itself. Out of the large number of suitable examples, I have chosen the perhaps most obvious, namely the way he presents the war against Hannibal (217-201 BCE) which forms the content of the so-called third decade of his work. These ten books, 21 to 30, have survived the centuries without any significant losses, bearing witness to their ongoing fascination even for readers in much later times. This success surely has to do with the dramatic events themselves, but it is also due to the way Livy tells them. This already applies to the structure of the whole decade which proves to be a carefully constructed narrative ${ }^{37}$ beginning with its own preface, ${ }^{38}$ showing an increasing line of Carthaginian successes and pre-

\footnotetext{
vires se ipsae conficiunt: [5] ego contra hoc quoque laboris praemium petam, ut me a conspectu malorum quae nostra tot per annos vidit aetas, tantisper certe dum prisca tota illa mente repeto, avertam, omnis expers curae quae scribentis animum, etsi non flectere a uero, sollicitum tamen efficere posset; see further Liv. 31.1.1-5 and 43.13.2; for the unusualness of the second thought, see Marincola 1997, 45-46: "Indeed, Livy's uniqueness is that [...] he presents the history as undertaken mainly for his personal pleasure."

34 For a reading of the praefatio in this vein, see now especially Vasaly 2015, 22-31, esp. 30-31. 35 For the longstanding discussion of the date, see e.g. Moles 1993, 151-152; Burton 2000; Pausch 2011, 32-33, and most recently Vasaly 2015, 3 (all of them with further references).

36 On this discrepancy as a part of classical historiography, see in general Pitcher 2009, 28-45. 37 See in general still Burck 1962 [1950] and now Levene 2010; for a more historical approach Walsh 1982.
}

38 Cf. Liv. 21.1-2.1. 
senting a peripeteia in the middle ${ }^{39}$ that changes the direction of events up to Hannibal's final defeat at Zama. ${ }^{40}$ Of course, the plotline was written by history herself, so to speak, but its artful arrangement is further enhanced by a number of previews, flashbacks and other narrative techniques that are most suitable to establish coherence on the one hand and to create suspense on the other.

Even on this general level of analysis, it is clear that Cicero's observation "nothing is better fitted to interest a reader than variety of circumstance and vicissitudes of fortune" ${ }^{41}$ is displayed to its full extent in this part of Livy's work. This becomes even more apparent when we now take a closer look at one of the many prominent events, namely Hannibal's passage to Italy and especially his crossing of the Alps. ${ }^{42}$ This surprising move and decisive step of his strategy has been much discussed by ancient and modern historians alike. For the classical authors, the debate is also closely connected to the question of how this pivotal episode should be presented in narrative terms. It is, once more, Polybius' harsh critique of his predecessors that allows us to get a glimpse of this debate (Plb. 3.47.6-9; 48.8): ${ }^{43}$

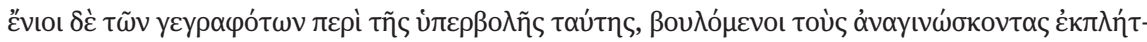

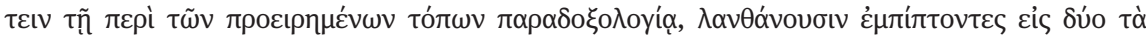

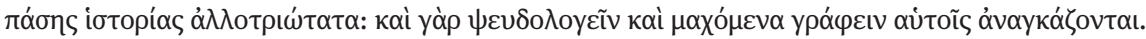

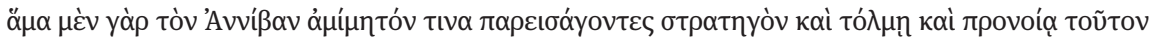

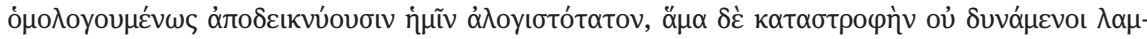

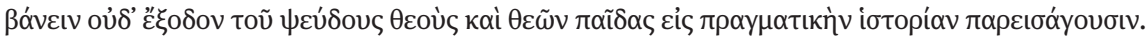

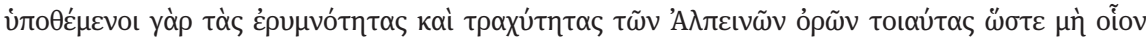

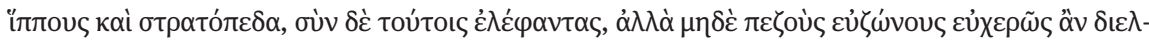

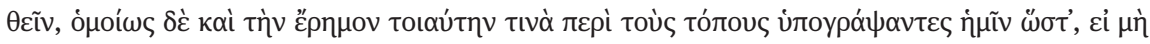

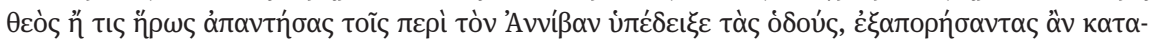

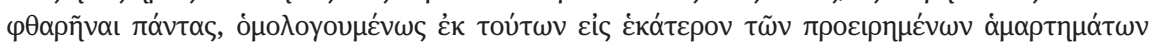
$\dot{\varepsilon} \mu \pi i \pi t o v \sigma$. [...].

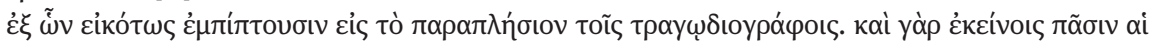

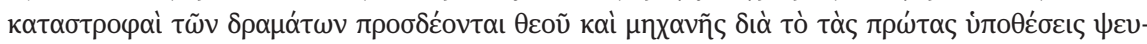

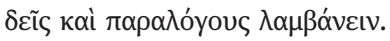

Some of the writers who have described this passage of the Alps, from the wish to impress their readers by the marvels they recount of these mountains, are betrayed into two vices ever most alien to true history; for they are compelled to make both false statements and statements which contradict each other. While on the one hand introducing Hannibal as a commander of unequalled courage and foresight, they incontestably represent him to us as entirely wanting in pruden-

39 The turn is mainly marked by the various elements of the $26^{\text {th }}$ book that are aimed at summing up the course of events and at highlighting the new balance of power (cf. ch. 1.1-3.12; 19.1-9; 37.1-38.5 and 41.3-25).

40 Cf. Liv. 30.29.5-38.5.

41 Cf. Cic. Fam. 5.12.4 (for full quotation, see above).

42 Cf. Liv. 21.21-21.38; for the historical background, see Händl-Sagawe 1995 ad loc. and Hoyos 2003, 98 -113; for the literary technique, see e. g. Witte 1910, 397-408; Burck 1962 [1950], 65 - 70; Gärtner 1975, 152-169; Feldherr 2009, esp. 317; Pausch 2011, 142-156, and Fabrizi 2015.

43 Text by Büttner-Wobst 1995; translation by Paton / Walbank / Habicht 2010. 


\begin{abstract}
ce, and again, being unable to bring their series of falsehoods to any close or issue they introduce gods and the sons of gods into the sober history of facts. By representing the Alps as being so steep and rugged that not only horses and troops accompanied by elephants, but even active men on foot would have difficulty in passing, and at the same time picturing to us the desolation of the country as being such, that unless some god or hero had met Hannibal and showed him the way, his whole army would have gone astray and perished utterly, they unquestionably fall into both the above vices [...].

The natural consequence is that they get into the same difficulties as tragic dramatists all of whom, to bring their dramas to a close, require a deus ex machina, as the data they choose on which to found their plots are false and contrary to reasonable probability.
\end{abstract}

As convincingly shown by David Levene in his book Livy on the Hannibalic War from 2010, the Roman historian was not only familiar both with Polybius' description of the Second Punic war and with his methodological remarks himself, but he also wrote his version of the events for readers with the same level of knowledge. The result is often the same as we have here, too: Livy refrains from using exactly the literary devices stigmatised by Polybius, but, nevertheless, finds a way to describe the events to a similar effect, like the historians criticised by Polybius - who, apart from that, contradicts his own verdicts in his very practice quite regularly. ${ }^{44}$

In this particular instance, therefore, Livy mentions no gods, be they mythological or dramaturgical, in the description of the crossing of the Alps itself. Contrary to Polybius, however, he lets his Hannibal pay a visit to the temple of Heracles (or rather the Carthaginian god Melqart, regularly identified with the Greek heros) at Cádiz before he starts his campaign against the Romans. ${ }^{45}$ While this detail alone looks reasonable enough, ${ }^{46}$ it is connected to his famous dream of a huge serpent by Livy's narrator, even if several other events have been mentioned in the meantime, by the explicit naming of Cádiz as his starting point (Liv. 21.22.6-9):47

\begin{abstract}
ab Gadibus Carthaginem ad hiberna exercitus rediit; atque inde profectus praeter Onussam urbem ad Hiberum maritima ora ducit. ibi fama est in quiete visum ab eo iuvenem divina specie qui se ab Iove diceret ducem in Italiam Hannibali missum; proinde sequeretur neque usquam a se deflecteret oculos. pavidum primo, nusquam circumspicientem aut respicientem, secutum; deinde cura ingenii humani cum, quidnam id esset quod respicere vetitus esset, agitaret animo, temperare oculis nequivisse; tum vidisse post sese serpentem mira magnitudine cum ingenti arborum ac virgultorum strage ferri ac post insequi cum fragore caeli nimbum. tum quae moles ea quidue prodigii esset quaerentem, audisse vastitatem Italiae esse; pergeret porro ire nec ultra inquireret sineretque fata in occulto esse.
\end{abstract}

44 On Hannibal's crossing of the Alps in particular, see Levene 2010, 149-155, esp. 154: "Livy is manifestly writing with Polybius' text directly in front of him, and moreover, assuming that at least some of his readers will realize that he is doing so. Polybius is Livy's source. Polybius is also Livy's target." 45 Cf. Liv. 21.21.9: Hannibal cum recensuisset omnium gentium auxilia, Gades profectus Herculi vota exsoluit novisque se obligat votis, si cetera prospera evenissent.

46 See especially Fabrizi 2015, 129-136, who offers a convincing interpretation of the use Hannibal might have made of this visit for the promotion of his campaign.

47 Text by Dorey 1971; translation by Foster 1929, both as in the following. 
From Gades Hannibal returned to New Carthage to the winter quarters of his army. Setting out from thence, he marched along the coast, past the city of Onusa, to the Ebro. It was there, as they tell, that he saw in his sleep a youth of godlike aspect, who declared that he was sent by Jupiter to lead him into Italy: let him follow, therefore, nor anywhere turn his eyes away from his guide. At first he was afraid and followed, neither looking to the right nor to the left, nor yet behind him; but presently wondering, with that curiosity to which all of us are prone, what it could be that he had been forbidden to look back upon, he was unable to command his eyes; then he saw behind him a serpent of monstrous size, that moved along with vast destruction of trees and underbrush, and a storm-cloud coming after, with loud claps of thunder; and, on his asking what this prodigious portent was, he was told that it was the devastation of Italy; he was therefore to go on, nor enquire further, but suffer destiny to be wrapped in darkness.

This dream surely is not invented by Livy, since it is already mentioned by Cicero in his dialogue De divinatione and explicitly described as part of the historiographical tradition on Hannibal. ${ }^{48}$ It is missing, however, from Polybius' account for obvious reasons. Although Livy has decided to follow his predecessor's verdict about divine intervention during the crossing of the Alps in the strict sense, he nonetheless chooses to incorporate this element of godly help into his narration, if only in the doubly rationalized form of a dream Hannibal is said to have had. The reason for this deviation from the Polybian precepts might well be that previews like this one, not given by the narrator himself, but only by the partially unreliable authority of a deity in a dream, are especially apt to activate the reader and to make him wonder about the further course of events. ${ }^{49}$ The resulting involvement into the story, however, leads to an enhancement of pleasure.

Another pleasure resulting from the reading of historiography can, at least according to Cicero, consist precisely "in the many quite unimportant details" (multa praeterea minime necessaria $)^{50}$ given by the narrator. This may look strange to a reader in our times, since we tend to consider too much elaborateness as a weakness of a story. For readers in antiquity, however, a detailed description, especially of foreign countries and people, offered an important stimulus to devote themselves to histor-

48 Cf. Cic. Div. 1.49: hoc item in Sileni, quem Coelius sequitur, Graeca historia est (is autem diligentissume res Hannibalis persecutus est): Hannibalem, cum cepisset Saguntum, visum esse in somnis a Iove in deorum concilium vocari; quo cum venisset, Iovem imperavisse, ut Italiae bellum inferret, ducemque ei unum e concilio datum, quo illum utentem cum exercitu progredi coepisse; tum ei ducem illum praecepisse ne respiceret; illum autem id diutius facere non potuisse elatumque cupiditate respexisse; tum visam beluam vastam et immanem circumplicatam serpentibus, quacumque incederet, omnia arbusta, virgulta, tecta pervertere, et eum admiratum quaesisse de deo quodnam illud esset tale monstrum, et deum respondisse vastitatem esse Italiae praecepisseque ut pergeret protinus, quid retro atque a tergo fieret ne laboraret; on the different functions in the works of the individual historians, see D’Arco 2002 and further Händl-Sagawe 1995, 142-144, and Levene 2010, 132-133.

49 See e.g. Fuhrmann 1983, 24: "Der Leser soll hier gewiß die hintergründige Ironie bemerken: das Traumgesicht sagt nichts Unwahres, es sagt jedoch nur die halbe Wahrheit." For an analysis of the internal focalisation in this passage, see further Tsitsiou-Chelidoni 2009, 537-538.

50 Cf. Cic. Fin. 5.52. 
iography, as is suggested not least by the large number of geographic and ethnographic digressions even in otherwise sober works such as Caesar's Commentarii. ${ }^{51}$ Hannibal leading his army into the terra incognita of the Alps offers, of course, a very suitable topic for a writer to meet the supposed interests of his readers. Interestingly enough, Polybius, in strict accordance with his principle of writing for the $\pi$ о $\lambda_{\mathrm{t}}$ -

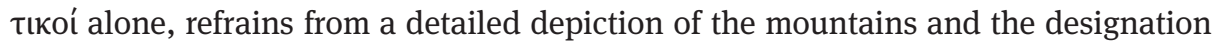
of their inhabitants. He even explains his denial at considerable length, above all by stressing that it is difficult for the reader to memorise place names hitherto unfamiliar to him and thus to gain a practical utility from them. ${ }^{52}$ Livy, by contrast, ignores in this case the example set by his predecessor and gives his readers what he assumes they want, as we see in our next example (Liv. 21.31.9-12):

sedatis certaminibus Allobrogum cum iam Alpes peteret, non recta regione iter instituit sed ad laevam in Tricastinos flexit; inde per extremam oram Vocontiorum agri tendit in Trigorios, haud usquam impedita via priusquam ad Druentiam flumen pervenit. is et ipse Alpinus amnis longe omnium Galliae fluminum difficillimus transitu est; nam cum aquae vim vehat ingentem, non tamen navium patiens est, quia nullis coercitus ripis, pluribus simul neque iisdem alveis fluens, nova semper [per] vada novosque gurgites - et ob eadem pediti quoque incerta via est - ad hoc saxa glareosa volvens, nihil stabile nec tutum ingredienti praebet; et tum forte imbribus auctus ingentem transgredientibus tumultum fecit, cum super cetera trepidatione ipsi sua atque incertis clamoribus turbarentur.

Having settled the contentions of the Allobroges, Hannibal was now ready for the Alps; but instead of marching directly towards them, he turned to the left, to the country of the Tricastini, and thence proceeded through the outer borders of the territory of the Vocontii to the Tricorii, by a road which nowhere presented any difficulties, until he came to the Druentia. This, too, is an Alpine river and by far the most difficult of all the rivers of Gaul to cross; for, though it brings down a vast volume of water, it does not admit of navigation, since, not being confined within any banks, but flowing at once in several channels, not always the same, it is ever forming new shallows and new pools - a fact which makes it dangerous for foot-passengers as well - besides which it rolls down jagged stones and affords no sure or stable footing to one who enters it. And at that time, as it happened, it was swollen with rains, and the crossing took place amidst the wildest tumult, for the men - besides their other difficulties - were confused by their own excitement and bewildered outcries.

For all its pseudo-accurate information, this description - like the remainder of Livy's account - has proved of little value for a reconstruction of Hannibal's exact route across the Alps. This question, however, has fascinated readers up to modern times and is still answered with a new solution on an almost regular basis both in more and in less academic publications..$^{53}$ The lasting interest in this taken by a broader public can give us a hint of the reactions of ancient readers as well. Contrary

51 Cf. Caes. Gal. 5.12-14 and 6.11-28; see e. g. Krebs 2006 and Woolf 2011, esp. 87-90. For an analysis of these digressions in the light of the possible audience of historical works in the Late Republic, see the contribution of Marine Miquel to the present volume.

52 Cf. Plb. 3.36-38, esp. 36.4-5.

53 Cf. Liv. 21.29.1-38.9; see e. g. Händl-Sagawe 1995, 193-248, and Hoyos 2006. 
to the modern focus on the understanding of the exact route Hannibal and his soldiers have taken, their curiosity seems to have been directed not least towards the emotional experience of the crossing of a frontier to the unknown and perhaps to see how it is "to explore strange new worlds, to seek out new life and new civilizations, to boldly go where no man has gone before."

The adventures of the Starship Enterprise and its crew, of course, belong to the realm of fiction. Nevertheless, that what we call belles lettres forms an inseparable part of historiography in antiquity remains true, even if it has been said so often that one gets tired of hearing it again and again. It is, therefore, a reasonable assumption that people in ancient times could read historical works with the same attitude and similar expectations that we rather apply to books of fiction. More astonishing, however, is the circumstance that - if we maintain the awkward parallelization for a last moment - the Livian Starship Enterprise is manned by Carthaginians. Whereas it is often taken for granted that the Roman readers for whom Livy wrote would only be willing to identify themselves with their historical equivalents and forefathers, the impact of this passage and of several others in the third decade would be significantly diminished if we were to assume that Roman readers took the Carthaginians above all as their enemies hoping that they would fail and never reach Italy at all. Although this approach would be perfectly sensible in historical categories, it is apparently not the mode in which the narration is meant to be read.

This becomes even clearer when Hannibal's army finally reaches the foot of the Alps. The Carthaginians' further encounter with the high mountains is repeatedly, though not consistently, presented from their point of view. A shifting focalisation in this vein, however, is an important technique for inviting the reader to adopt the perspective of a certain character and, thus, both to make him more activated and to enhance his involvement in the further course of the events. We find an example for this narrative strategy in our next passage which additionally comprises several words connected to the semantic field of seeing which implicitly emphasize the effect of the focalisation (Liv. 21.32.6-8): ${ }^{54}$

Hannibal ab Druentia campestri maxime itinere ad Alpes cum bona pace incolentium ea loca Gallorum pervenit. tum, quamquam fama prius, qua incerta in maius vero ferri solent, praecepta res erat, tamen ex propinquo visa montium altitudo nivesque caelo prope immixtae, tecta informia imposita rupibus, pecora iumentaque torrida frigore, homines intonsi et inculti, animalia inanimaque omnia rigentia gelu, cetera visu quam dictu foediora terrorem renovarunt. erigentibus in primos agmen clivos apparuerunt imminentes tumulos insidentes montani, qui, si valles occultiores insedissent, coorti ad pugnam repente ingentem fugam stragemque dedissent.

Hannibal, leaving the Druentia, and advancing for the most part through a champaign country, reached the Alps without being molested by the Gauls who inhabited those regions. Then, though report, which is wont to exaggerate uncertain dangers, had already taught them what to expect still, the near view of the lofty mountains, with their snows almost merging in the

54 See further Tsitsiou-Chelidoni 2009; Pausch 2011, 149-152, and Fabrizi 2015, 136-140. 
sky; the shapeless hovels perched on crags; the frost-bitten flocks and beasts of burden; the shaggy, unkempt men; animals and inanimate objects alike stiff with cold, and all more dreadful to look upon than words can tell, renewed their consternation. As their column began to mount the first slopes, mountaineers were discovered posted on the heights above, who, had they lain concealed in hidden valleys, might have sprung out suddenly and attacked them with great rout and slaughter.

The last sentence offers a particularly good example, as two narrative techniques are combined: first, the Carthaginian are presented here in the form of a dativus iudicantis which is used again to highlight the circumstance that it is their perspective that we are following. Second, another literary device follows closely which is usually employed to create suspense and, in doing so, to relate the reader to the fate of the character in peril: the narrator imagines that something dreadful would have happened if some other thing had not occurred and saved the situation at the very last moment. Such elements of counterfactual history ${ }^{55}$ or of possible worlds within a narration are used by Livy both at large - his digression on Alexander the Great's hypothetical war with Rome offering the best known example $e^{56}$ - and on a smaller scale, as in our passage, ${ }^{57}$ when nothing more than a contrafactual conditional clause is necessary to evoke the imagination of 'what almost happened' or of a 'Beinahe-Episode', as it has been called by Heinz-Günther Nesselrath in his study on the use of this technique in epic poetry. ${ }^{58}$ Both forms, however, are usually employed from the perspective of the protagonist himself, who gets into danger and finally is rescued. But in our case the narrator apparently expects his reader to worry about the survival of the very same Carthaginians that later in the book will be the utmost threat to his fellow Romans. This alternation of identification looks strange in strictly historical terms, but it greatly enhances the pleasures of reading in the first chapters of Livy's third decade.

In the same vein, I would also like to read another famous passage of Livy's 'Hannibal crossing the Alps' section that usually is understood quite differently. I am referring to the speech that Livy has Hannibal deliver to his soldiers when they encounter even more severe difficulties on their way down on the Italian side. It is summarised in oratio obliqua by the narrator (Liv. 21.35.7-9): ${ }^{59}$

per omnia nive oppleta cum signis prima luce motis segniter agmen incederet pigritiaque et desperatio in omnium voltu emineret, praegressus signa Hannibal in promunturio quodam, unde longe et late prospectus erat, consistere iussis militibus Italiam ostentat subiectosque Alpinis montibus Circumpadanos campos moeniaque eos tum transcendere non Italiae modo, sed

55 See in general Demandt 2001 [1984]; Suerbaum 1997 and Weber 2000.

56 Cf. Liv. 9.17.1-19.17; see e. g. Morello 2002, especially 83: "[...] traditional readings have underestimated the value of a counterfactual digression as a tool for historical thinking."

57 For more examples, see Pausch 2011, especially 200-202.

58 See Nesselrath 1992.

59 For the manifold historical problems attached to this passage, see Händl-Sagawe 1995, 235-236. 
etiam urbis Romanae; cetera plana, proclivia fore; uno aut summum altero proelio arcem et caput Italiae in manu ac potestate habituros.

The ground was everywhere covered deep with snow when at dawn they began to march, and as the column moved slowly on, dejection and despair were to be read in every countenance. Then Hannibal, who had gone on before the standards, made the army halt on a certain promontory which commanded an extensive prospect, and pointing out Italy to them, and just under the Alps the plains about the Po, he told them that they were now scaling the ramparts not only of Italy, but of Rome itself; the rest of the way would be level or downhill; and after one, or, at the most, two battles, they would have in their hands and in their power the citadel and capital of Italy.

To be sure, Polybius reports a similar address in the same situation. ${ }^{60}$ But, again according to his principles set out above, he has his Hannibal restrict himself much more to the necessary motivation of his men and, for that purpose, lets him point only to the most imminent future. ${ }^{61}$ Livy, however, seizes the opportunity of this speech to give a much more pronounced preview of the events to come. Intriguingly, this outlook into the future is given from a clear Carthaginian perspective again. In this case, it applies not only literally to the point of view, since the speech is accompanied by a panoramic - although fictitious - view of the Italian peninsula, but also to the content itself, since Hannibal unfolds a very optimistic vision of the further course of the events for himself and his men. Even if this scenario will soon be refuted by the following narrative and it will turn out that the Carthaginians will have to face so much more than "one, or, at the most, two battles", in my opinion there is here more at stake than just a kind of 'tragic irony', easily detected by Roman readers and received with nothing more than 'Schadenfreude' at the cost of a general failing to keep the promises he made to his soldiers.

Passages like this one are rather meant to unsettle the reader and to shake his confidence about the assuredly 'happy ending' of the story he is reading. To be sure, after a moment of reflection he will be able to reduce the suspension he might have felt by invoking his historical knowledge. Nevertheless, such narrative strategies are very suitable to increase the pleasure one might get from reading an historical account. But even besides their contribution to the delectatio of the reader, the same techniques are relevant for the utilitas of a work of historiography, too. I will not go into detail here, but I think a plausible argument can be made that both the shifting of the point of view and the use of strongly focalized previews into the narrative future are pivotal elements which enhance the understanding of history as well. ${ }^{62}$ This is especially the case when we are dealing with a development of events that is influenced by the decisions of the historical agents and thus has been open to

60 Cf. Plb. 3.54.1-3.

61 For further comparison of the both versions, see e.g. Fabrizi 2015, 140-143, and Pausch 2016, 317-319.

62 See Pausch 2011, 191-250. 
take other courses as well. Multiperspectivity and focalisation, then, can help to teach the reader about what in history is contingent and what perhaps is not. ${ }^{63}$

\section{Livy's imagined reader and the audience of historiography}

Coming back to the topic of this present paper, however, I hope the passages discussed above have been able to show that Livy has written this part of his work at least for a reader who will experience the full emotional force of the events and thus will be able to receive the kind of pleasure named by Cicero as an important motive for reading historiography. That the purpose of this thrill and, thereby, presumably of the identification of Roman readers is formed - even if only at times and not continuously - by Hannibal and his Carthaginian soldiers, is a clear indication that Livy, for all his dutiful affirmation in the praefatio, in fact has written much more than a history ad maiorem gloriam Romae. The same applies to the putting of exempla at the reader's disposal, to which Livy's work is too often reduced. To be sure, we find a huge number of relevant passages in his monumental work that can be used in this way. But then, there are large parts of $A b$ urbe condita that like the Hannibal's crossing of the Alps - do not contain any clear-cut examples waiting to be re-used by a prospective politician or general.

It is, therefore, legitimate to assume that history at this time was not written for Polybius' по入ıткко alone, but either for an imagined reader with diverse interests or for different readers with their respective motives at the same time. The comparatively well-documented example of Cicero, however, suggests that the former might have been the rule: a reader that wanted to gain useful knowledge from his reading of historiography as well as the pleasure of being involved into a good story. That the opinions of Cicero and of his contemporaries correspond closely in this point suggests, furthermore, that the traditional picture of a degeneration of proper historiography into mere literature only after the end of the Roman Republic is nothing more than a gross simplification. This being said, it might be a fruitful approach to rethink the similar argument used to explain the literary value of historical works in other epochs as well. Despite the necessary differentiation, the understanding of classical historiography undoubtedly profits from the regular comparison of the approaches taken in the analysis of the individual authors.

63 See Maier 2012, 103-140. 


\section{Bibliography}

Burck, E. (1962 [1950]), Einführung in die dritte Dekade des Livius, Heidelberg.

Burton, P.J. (2000), “The Last Republican Historian: A New Date for the Composition of Livy's First Pentad", in: Historia 49, 429-446.

Büttner-Wobst, T. (1995 [1893]), Polybii historiae, vol. III, libri ix-xix, Stuttgart.

Cohn, D. (1999), The Distinction of Fiction, Baltimore.

D’Arco, I. (2002), “Il sogno premonitore di Annibale e il pericolo delle Alpi”, in: QS 55, 145-162.

de Franchis, M. (2014), “Pour qui écrit Tite-Live?”, in: J.-C. Julhe (ed.), Pratiques latines de la dédicace - Permanence et mutations, de l'Antiquité à la Renaissance, Paris, 189-213.

Demandt, A. (2001 [1984]), Ungeschehene Geschichte. Ein Traktat über die Frage: "Was wäre geschehen, wenn ...?", Göttingen.

Dorey, T.A. (1971), Titi Livi: ab urbe condita, Bücher 21-22, Leipzig.

Fabrizi, V. (2015), "Hannibal's March and Roman Imperial Space in Livy, Ab urbe condita, Book 21", in: Philologus 159, 118-155.

Feldherr, A. (2003), “Cicero and the Invention of 'Literary' History”, in: U. Eigler et al. (eds.), Formen römischer Geschichtsschreibung von den Anfängen bis Livius, Darmstadt, 196-212.

Feldherr, A. (2009), “Delusions of Grandeur: Lucretian 'Passages' in Livy”, in: P. Hardie (ed.), Paradox and the Marvellous in Augustan Literature and Culture, Oxford, 310-329.

Fleck, M. (1993), Cicero als Historiker, Stuttgart.

Foster, B.O. (1929), Livy: Books 21-22, London.

Foucher, A. (2000), “Nature et formes de l' 'histoire tragique' à Rome”, in: Latomus 59, 773-801. Fox, M. (2007), Cicero's Philosophy of History, Oxford.

Fuhrmann, M. (1983), "Narrative Techniken im Dienste der Geschichtsschreibung (Livius, Buch 21-22). Eine Skizze”, in: E. Lefèvre / E. Olshausen (eds.), Livius. Werk und Rezeption, Festschrift für Erich Burck, Munich, 19-29.

Funari, R. (2011), Corpus dei Papiri Storici greci e latini. Parte B: Storici latini. 1: Autori noti. Vol. 1: Titus Livius, Rome.

Händl-Sagawe, U. (1995), Der Beginn des 2. Punischen Krieges. Ein historisch-kritischer Kommentar zu Livius Buch 21, Munich.

Gärtner, H.A. (1975), Beobachtungen zu Bauelementen in der antiken Historiographie besonders bei Livius und Caesar, Wiesbaden.

Genette, G. (1990), “Fictional Narrative, Factual Narrative”, in: Poetics Today 11, 755-774.

Hall, J. (1998), “Cicero to Lucceius (Fam. 5.12) in its Social Context: valde bella?", in: CPh 93, $308-321$.

Hau, L.I. (2016), Moral History from Herodotus to Diodorus, Edinburgh.

Horster, M. (2018), "Geschichte und Geschichten im Altag”, in: A. Kolb (ed.), Literacy in Ancient Everyday Life, Berlin / Boston, 363-386.

Hose, M. (1994), Erneuerung der Vergangenheit. Die Historiker im Imperium Romanum von Florus bis Cassius Dio, Stuttgart.

Hose, M. (2009), “'Exzentrische' Formen der Historiographie im Hellenismus”, in: J. Frey / C.K. Rothschild / J. Schröter (eds.), Die Apostelgeschichte im Kontext antiker und frühchristlicher Historiographie, Berlin, 182-213.

Hoyos, D. (2003), Hannibal's Dynasty: Power and Politics in the Western Mediterranean, 247-183 B.C., London.

Hoyos, D. (2006), "Crossing the Durance with Hannibal and Livy: the Route to the Pass", in: Klio $88,408-465$.

Krebs, C.B. (2006), “'Imaginary Geography’ in Caesar’s Bellum Gallicum”, in: AJPh 127, 111-136. 
Leeman, A.D. (1955), “Le genre et le style historique à Rome. Théorie et pratique”, in: REL 33, $183-208$.

Levene, D.S. (2010), Livy on the Hannibalic War, Oxford.

Maier, F.K. (2012), Überall mit dem Unerwarteten rechnen. Die Kontingenz historischer Prozesse bei Polybios, Munich.

Malitz, J. (1990), "Das Interesse an der Geschichte. Die griechische Geschichte und ihr Publikum”, in: H. Verdin / G. Schepens / E. de Keyser (eds.), Purposes of History: Studies in Greek Historiography from the 4 th to the 2nd Centuries B.C.: Proceedings of the International Colloquium Leuven, 24-26 May 1988, Leuven, 323-349.

Marincola, J. (1997), Authority and Tradition in Ancient Historiography, Cambridge.

Marincola, J. (2009), "Ancient Audiences and Expectations", in: A. Feldherr (ed.), The Cambridge Companion to The Roman Historians, Cambridge, 11-23.

Meineck, P. / Konstan, D. (eds.) (2014), Combat Trauma and the Ancient Greeks, Basingstoke.

Mineo, B. (2006), Tite-Live et l'histoire de Rome, Paris.

Moles, J. (1993), “Livy's Preface”, in: PCPhS 39, 141-168.

Momigliano, A. (1978), "The Historians of the Classical World and their Audiences: Some Suggestions", in: ASNP 3.8, 59-75.

Morello, R. (2002), “Livy's Alexander Digression (9.17-19). Counterfactuals and Apologetics”, in: JRS 92, 62-85.

Näf, B. (2010), Antike Geschichtsschreibung. Form - Leistung - Wirkung, Stuttgart.

Nesselrath, H.-G. (1992), Ungeschehenes Geschehen. 'Beinahe-Episoden' im Griechischen und Römischen Epos, Stuttgart.

Nicolai, R. (1992), La storiografia nell'educazione antica, Pisa.

Nicolai, R. (2007), "The Place of Historiography in the Ancient World", in: J. Marincola (ed.), $A$ Companion to Greek and Roman Historiography, vols. I-II, Malden, MA, 13-26.

Paton, W.R. (1993 [1925]), Polybius: The Histories. Vol. IV, Books 9-15, London.

Paton, W.R. / Walbank, F.W. / Habicht, C. (2010), Polybius: The Histories. Vol. Il, Books 3-4 (revised edition), London.

Paul, G.M. (1982), “Urbs capta: Sketch of an Ancient Literary Motif”, in: Phoenix 36, 144-155.

Pausch, D. (2011), Livius und der Leser. Narrative Strukturen in ab urbe condita, Munich.

Pausch, D. (2016), "On the Shoulders of Greeks? Future Time in Livy's ab urbe condita", in: A. Lianeri (ed.), Knowing Future Time in and through Greek Historiography, Berlin, 311-327.

Pausch, D. (2018), “Lost in Reception? Polybius' Paradoxical Impact on Writing History in Republican Rome”, in: N. Miltsios / M. Tamiolaki (eds.), Polybius and his Legacy, Berlin / Boston, 357-380.

Pitcher, L.V. (2009), Writing Ancient History: An Introduction to Classical Historiography, London.

Rackham, H. (1961 [1914]), Cicero: De finibus bonorum et malorum, London.

Reitzenstein, R. (1906), Hellenistische Wundererzählungen, Leipzig.

Schiche, T. (1961), M. Tullius Cicero. Fasc. 43: De finibus bonorum et malorum, Stuttgart (= Leipzig 1915).

Shackleton Bailey, D.R. (1988), M. Tulli Ciceronis epistulae ad familiares: libri I-XVI, Stuttgart.

Shuckburgh, E.S. (1908-1909), The Letters of Cicero, London.

Suerbaum, W. (1997), “Am Scheideweg zur Zukunft. Alternative Geschehensverläufe bei römischen Historikern", in: Gymnasium 104, 36-54.

Tsitsiou-Chelidoni, C. (2009), "History beyond Literature: Interpreting the 'Internally Focalized' Narrative in Livy's Ab urbe Condita", in: J. Grethlein / A. Rengakos (eds.), Narratology and Interpretation. The Content of Narrative Form in Ancient Literature, Berlin, 527-554.

Vasaly, A. (2015), Livy's Political Philosophy: Power and Personality in Early Rome, Cambridge.

Verdin, H. / Schepens, G. / de Keyser, E. (eds.) (1990), Purposes of History. Studies in Greek Historiography from the 4 th to the 2nd Centuries $B C$, Leuven. 
Walsh, P.G. (1982), “Livy and the Aims of historia: An Analysis of the Third Decade”, in: ANRW 2.30.2, Berlin, 1058-1074.

Walter, U. (2004), Memoria und res publica. Zur Geschichtskultur im republikanischen Rom, Frankfurt.

Weber, G. (2000), “Vom Sinn kontrafaktischer Geschichte”, in: K. Brodersen (ed.), Virtuelle Antike. Wendepunkte der Alten Geschichte, Darmstadt, 11-23.

Wiseman, T.P. (2015), The Roman Audience. Classical Literature as Social History, Oxford.

Witte, K. (1910), “Über die Form der Darstellung in Livius' Geschichtswerk”, in: RhM 65, 270-305 and 359-419.

Woolf, G. (2011), Tales of the Barbarians. Ethnography and Empire in the Roman West, Chichester. 